\title{
Vocal behaviour and feeding ecology of killer whales Orcinus orca around Shetland, UK
}

\author{
Volker B. Deecke ${ }^{1, *}$, Milaja Nykänen ${ }^{1}$, Andrew D. Foote ${ }^{2,3}$, Vincent M. Janik ${ }^{1}$ \\ ${ }^{1}$ Sea Mammal Research Unit, Scottish Oceans Institute, University of St. Andrews, St. Andrews, KY16 8LB, UK \\ ${ }^{2}$ Lighthouse Field Station, University of Aberdeen, Cromarty, Ross-shire, IV11 8YJ, UK \\ ${ }^{3}$ The Centre for GeoGenetics, Natural History Museum of Denmark, University of Copenhagen, Copenhagen 1350, Denmark
}

\begin{abstract}
Killer whales Orcinus orca are sighted regularly off Shetland, UK, but little is known about their numbers, diet and population identity. We aimed to relate vocal behaviour to diet of killer whales around Shetland in order to investigate population structure and differences in feeding strategies. Fieldwork was conducted in the summers of 2008 and 2009. We located killer whales through a sightings network and shore-based scans and collected photo-ID data, behavioural information, feeding data and acoustic recordings from a small boat. The majority of encounters $(n=14)$ were of small groups (1 to 15 individuals) travelling close to shore and feeding on marine mammals. Two encounters were with large groups (20+ individuals) feeding on herring Clupea harengus farther offshore. Seal-hunting groups vocalised rarely, producing pulsed calls, echolocation clicks and whistles almost exclusively when surface-active or milling after a kill. Herring-eating groups were largely silent during one encounter, but very vocal during the other. Analysis of pulsed calls identified 6 stereotyped call types for seal-hunting groups and 7 for herring-eating groups. No call types were shared between both kinds of groups. The vocal behaviour of seal-hunting groups showed striking parallels to that of Pacific marine mammal specialists and presumably evolved to decrease detection by acoustically sensitive prey. One call type produced by Shetland herring-eating killer whales matched a vocalisation that a previous study had described from Iceland and identified as a possible herding call that may function to concentrate herring during feeding. These findings point to behavioural and dietary specialisation among Shetland killer whales, which should be taken into account when making management decisions affecting these animals.
\end{abstract}

KEY WORDS: Dietary specialisation ' Vocal behaviour ' Feeding ecology ' Killer whale $\cdot$ North Atlantic

Resale or republication not permitted without written consent of the publisher

\section{INTRODUCTION}

Killer whales Orcinus orca are top predators in the marine environment and, being homeotherms, have a high energetic requirement (Williams et al. 2004). It has therefore been suggested that predation by killer whales has a substantial structuring influence in marine ecosystems and could be largely responsible for large-scale declines in pinnipeds and sea otters in the North Pacific (Estes et al. 1998, Springer et al. 2003, Williams et al. 2004). A similar decline has been observed in Scottish waters: harbour seals Phoca vitulina in Shetland and Orkney declined by $40 \%$ between
2000 and 2006 (Lonergan et al. 2007). Harbour seals are a preferred prey of killer whales in the northeastern Pacific (Ford et al. 1998, Saulitis et al. 2000, Dahlheim \& White 2010), and predation on harbour seals has also been reported from killer whales around Shetland and Orkney (Weir 2002, Bolt et al. 2009).

While predation by killer whales could be an important factor in the decline in harbour seals off northern Scotland (Bolt et al. 2009), assessing the impact of killer whale predation requires precise information on abundance, distribution, diet and population identity of local killer whales. Killer whales have been sighted regularly in Shetland waters since the 1970s (Evans 
1988, Weir 2002). Published records include sightings of large groups offshore often associated with trawl fisheries for mackerel (Couperus 1994, Luque et al. 2006, Foote et al. 2010), as well as smaller groups close to shore reported to take marine mammals (Evans 1988, Weir 2002, Foote et al. 2010). However, information on the number, diet, social structure and population identity of killer whales around Shetland is currently limited.

As a species, killer whales feed on a wide range of prey including elasmobranchs, teleosts, marine reptiles, birds and mammals (e.g. Rice 1968, Jefferson et al. 1991, Pitman \& Dutton 2004, Ford et al. 2011). Research in northeastern Pacific and Antarctic waters suggests a high degree of dietary specialisation, with different sympatric populations specialising on fish and sea mammals respectively (Ford et al. 1998, Saulitis et al. 2000, Pitman \& Ensor 2003). The situation in the North Atlantic is less clear. While there is evidence that the diet of some populations is highly specialised, stable isotope analysis suggests that in others, individuals with the same mitochondrial haplotype feed at different trophic levels (Foote et al. 2009), which could point to a greater niche width for these populations.

Studies of the vocal behaviour of different killer whale populations have revealed quantitative and qualitative differences related to dietary specialisation. Like other delphinids, killer whales produce 3 types of vocalisations: echolocation clicks are thought to function primarily for orientation and prey detection, whereas pulsed calls and whistles are thought to be communicative signals (Ford 1989, Thomsen et al. 2002, Janik 2009). Many pulsed calls and some whistles are stereotyped, show population-specific and group-specific variation, and can thus be used to identify acoustic lineages (Ford \& Fisher 1982, Yurk et al. 2002, Riesch et al. 2006). In addition, mammal-hunting killer whales in the northeastern Pacific produce echolocation clicks, pulsed calls and whistles at significantly lower rates compared to sympatric fish eaters (Barrett-Lennard et al. 1996, Riesch et al. 2006, Riesch \& Deecke 2011). Whereas many fishes have poor hearing sensitivity at the frequencies of killer whale vocalisations, marine mammals can detect killer whale vocalisations at significant distances, and this eavesdropping makes vocal behaviour costly for mammalhunting killer whales (Barrett-Lennard et al. 1996, Deecke et al. 2002, 2005). The overall amount of vocal behaviour may therefore also provide information about feeding specialisation in other populations.

The objective of the present study was to determine the diet and analyse the vocalisations of killer whales in relation to their foraging behaviour around Shetland. First, we investigated the frequency of occurrence of the different sound types (echolocation clicks, whistles and pulsed calls) to see if usage and behavioural context of vocal activity are more characteristic of mammal- or fish-eating killer whales. We would expect to see much reduced levels of vocal behaviour in groups hunting for acoustically sensitive marine mammals compared to those feeding on fish. Second, we described the stereotyped pulsed calls produced by different groups recorded in Shetland and investigated group-specific variation in call repertoires, which could indicate the presence of several different vocal traditions in Shetland waters.

\section{MATERIALS AND METHODS}

Dedicated fieldwork was conducted in Shetland between 22 May and 17 August 2008 and between 29 April and 11 July 2009. We searched for killer whales from elevated points on land and set up a sighting network to obtain information on killer whale movements from ferry personnel, fishing crews and members of the general public. Upon finding whales or receiving sighting information, we launched a $6 \mathrm{~m}$ rigid-hulled inflatable powered by two $40 \mathrm{hp}$ outboard engines to approach the animals whenever sea state, weather conditions and daylight permitted.

Identification photographs were taken using digital SLR cameras (Canon EOS 20D, Canon EOS 40D, Nikon D100 or Nikon D700) with telephoto lenses (Canon EF 70-200 mm F2.8 zoom lens, Sigma 100-300 mm F4 EX DG APO HSM zoom lens or Nikkor $300 \mathrm{~mm}$ F4 AF-S fixed lens). Whales were assigned 3-digit identification numbers in the order they were first identified. Once sufficient photographs of all group members had been obtained, we followed the animals at a distance of 100 to $500 \mathrm{~m}$ for a maximum of $4 \mathrm{~h}$ or as long as conditions permitted and used focal group sampling (Altmann 1974) to quantify behaviour and vocal activity. At every surfacing, we noted our distance to the group and its behavioural state. We also recorded any evidence of feeding and collected prey remains whenever possible. We divided behaviour into 'travel', 'slow travel', 'milling', 'surface-active' and 'after kill' using the method of Deecke et al. (2005), which classifies behavioural states depending on the animals' swim speed, surface behaviour and synchronicity. This classification does not make assumptions about whether animals are actively foraging, but in Pacific transient killer whales, confirmed kills are typically preceded by travel, slow travel or milling (Deecke et al. 2005). Distances were estimated and confirmed using laser range finders (Leica Geovid $7 \times 42 \mathrm{BDA}$ ) whenever possible. At distances $<500 \mathrm{~m}$, estimates typically have an average error of $\pm 11 \%$ (Deecke et al. 2005). 
Acoustic recordings were made using a towable hydrophone array consisting of 2 AQ-4 transducers (Benthos) with HP-02 pre-amplifiers (Magrec) towed $60 \mathrm{~m}$ behind the boat at a depth of approximately 5 to $20 \mathrm{~m}$. Sound was recorded on a Marantz PMD671 solid-state recorder (D\&M Professional) with a sampling rate of $96 \mathrm{kHz}$. The system's frequency response was flat $( \pm 3 \mathrm{~dB})$ from 0.1 to $40 \mathrm{kHz}$. When analysing the context of vocal behaviour, we only included sections when the animals were within $500 \mathrm{~m}$ of the boat to minimise the number of faint vocalisations missed. These sections were analysed with Adobe Audition 2.0 (Adobe Systems) using real-time spectral analysis to determine the number of detectable pulsed calls, whistles and echolocation click trains. We also examined any vocalisations for signs of strong multi-pathing, which would suggest that they came from distant animals rather than the focal group. To establish vocal repertoires, quality of pulsed calls was then scored by the first author on a scale from 1 (poor) to 5 (excellent), taking into account the call's signal-to-noise ratio, clarity and overlap with other vocalisations. Frequency contours (fundamental frequency as a function of time) were extracted from calls with a quality rating of 3 and higher using a combination of algorithms (Buck \& Tyack 1993, Deecke et al. 1999), and contours were divided into call types using the automated ARTwarp categorisation method of Deecke \& Janik (2006). Any categories represented by a single example were not retained, and categories that only differed in 1 part of the call were labelled as sub-types of a common call type.

Only predation events where prey remains were clearly seen, photographed or recovered were listed as confirmed kills. Species identity of the prey was established visually from photographs or through molecular analysis of prey remains. Prey remains were wrapped in aluminium foil and frozen at $-20^{\circ} \mathrm{C}$ without preservative within $10 \mathrm{~h}$ after collection. For the molecular identification, DNA was extracted from prey remains using a Qiagen DNeasy kit following the manufacturer's guidelines. The mitochondrial DNA (mtDNA) control region of mammalian samples was amplified with 2 sets of primers, first using universal primers MTCRf and MTCRr (Hoelzel et al. 1998) and secondly using primers L16371 and HI6571 (Lamont et al. 1996) specifically designed for harbour seals. For DNA extracted from fish samples, a $682 \mathrm{bp}$ fragment of the mtDNA control region was amplified using primers $Q$ and B (Lee et al. 1995).

Each $25 \mu \mathrm{l}$ PCR contained $1 \mu \mathrm{l}$ extracted DNA, $1 \times$ PCR buffer, $1 \mathrm{mM} \mathrm{MgCl}_{2}, 400 \mathrm{nM}$ of each primer, $0.1 \mathrm{mM}$ mixed dNTPs and $0.1 \mu \mathrm{l}$ AmpliTaq Gold enzyme (Applied Biosystems). PCR amplifications were performed using an MJ Thermocycler with a 4 min activation step at $95^{\circ} \mathrm{C}$, followed by 50 cycles of $95^{\circ} \mathrm{C}$ for $20 \mathrm{~s}, 54^{\circ} \mathrm{C}$ for
$20 \mathrm{~s}, 72^{\circ} \mathrm{C}$ for $20 \mathrm{~s}$ and a final extension period of $72^{\circ} \mathrm{C}$ for $7 \mathrm{~min}$. The amplified PCR products were purified using the Invitek PCRapace purification kit. Purified products were sequenced in both directions using the PCR primers and ABI sequencing chemistry by a commercial sequencing service (Macrogen, Seoul, South Korea). Sequences were compared with sequences in GenBank using the BLAST algorithm (Altschul et al. 1990).

\section{RESULTS}

We sighted killer whales on 22 occasions and obtained usable photo-identification data on 18 of these. Two encounters involved animals for which we had neither feeding data nor acoustic recordings, and these were removed from the analysis. The majority $(\mathrm{n}=14)$ of the remaining encounters were of small groups (1 to 15 individuals) travelling close to shore (often within a few body lengths of the shoreline). The high number of resightings of individuals between the 2 field seasons (Table 1) suggests a small assemblage of animals with a high degree of site fidelity. We confirmed successful predation of marine mammals during 4 encounters (Table 1): prey remains were recovered on 4 July 2008 and 24 May 2009, and both samples were identified as harbour seals by the BLAST algorithm (see the supplement; www.int-res.com/articles/suppl/b013p079_ supp.pdf). On 2 July 2008, we photographed a harbour seal being attacked and killed, and on 28 June 2009, we observed a large section of mammalian intestine floating at the surface following an attack. In 2 additional encounters, we observed unsuccessful attacks on seals (1 grey seal Halichoerus grypus and 1 unidentified seal). On 20 May 2009, a large blood plume in the water near a milling group indicated a predation event. This is listed as a probable kill of an unidentified marine mammal in Table 1. All individuals recorded travelling close to shore were either involved in a confirmed kill of a marine mammal or were encountered in close association with individuals that were involved in a confirmed marine mammal kill (Table 1). We did not detect any evidence that these animals targeted fish. Two additional encounters were with large groups (20+ individuals) more than 3 nautical miles off Unst. We recovered fish swim bladders around feeding whales in both encounters (2 swim bladders on 29 June 2009 and 4 on 1 July 2009). We were unable to obtain a sequence from 1 swim bladder collected on 1 July 2009; all others were identified as Atlantic herring Clupea harengus (see the supplement for details). The sampling location implies that these herring were from the North Sea stock (Mariani et al. 2005, Ruzzante et al. 2006). 
Table 1. Orcinus orca. Summaries of encounters of killer whales around Shetland in the summers of 2008 and 2009 . All encounters with individuals for which diet and/or acoustic data are available are shown. For focal follows, observed behavioural states and any sounds recorded are also listed. Details on pulsed call types given in Fig. 3

\begin{tabular}{|c|c|c|c|c|c|}
\hline Date & Time (h) & Individuals present & Predation & Behavioural states & Acoustic behaviour \\
\hline 12 Jun 08 & $14: 59$ & $032,064,065,066,067$ & - & Not monitored & Not monitored \\
\hline 12 Jun 08 & $17: 45$ & 014 & - & Not monitored & Not monitored \\
\hline 22 Jun 08 & 11:06 & $032,064,065,066,067$ & - & Not monitored & Not monitored \\
\hline 30 Jun 08 & $20: 48$ & $032,064,065,066,067$ & - & $\begin{array}{l}\text { Milling, slow travel, } \\
\text { travel }\end{array}$ & Echolocation \\
\hline $02 \mathrm{Jul} 08^{\mathrm{a}}$ & $10: 25$ & 014 & $\begin{array}{l}\text { Confirmed kill } \\
\text { of harbour seal }\end{array}$ & Not monitored & Not monitored \\
\hline $04 \mathrm{Jul} 08$ & $15: 31$ & $032,064,065,066,067$ & $\begin{array}{l}\text { Confirmed kill } \\
\text { of harbour seal }\end{array}$ & After kill & $\begin{array}{l}\text { Pulsed calls (NASh05, variable), } \\
\text { echolocation, whistles }\end{array}$ \\
\hline 14 Jul 08 & $15: 51$ & $064,066,067+2$ & - & Not monitored & Not monitored \\
\hline $18 \mathrm{Jul} 08$ & $15: 38$ & $032,064,065,066,067$ & - & Surface-active, travel & Pulsed calls (variable) \\
\hline 15 Aug 08 & $15: 17$ & $027,034,072,073$ & - & Not monitored & Not monitored \\
\hline 20 May 09 & $13: 15$ & $032,064,065,066,067$ & $\begin{array}{l}\text { Probable kill of } \\
\text { unidentified } \\
\text { marine mammal }\end{array}$ & After kill, travel & $\begin{array}{l}\text { Pulsed calls (variable), } \\
\text { echolocation, whistles }\end{array}$ \\
\hline 24 May 09 & $20: 57$ & $032,064,065,066,067$ & $\begin{array}{l}\text { Confirmed kill } \\
\text { of harbour seal }\end{array}$ & $\begin{array}{l}\text { After kill, surface- } \\
\text { active, travel }\end{array}$ & Silent \\
\hline 31 May 09 & $15: 12$ & $032,064,065,066,067$ & $\begin{array}{l}\text { Possible attack on } \\
\text { unidentified seal }\end{array}$ & $\begin{array}{l}\text { Milling, slow travel, } \\
\text { travel }\end{array}$ & Pulsed calls (variable), whistles \\
\hline 20 Jun 09 & $15: 07$ & $027,034,072,073$ & $\begin{array}{l}\text { Probable attack } \\
\text { on grey seal }\end{array}$ & Milling, travel & Echolocation \\
\hline 28 Jun 09 & $15: 20$ & $\begin{array}{l}014,018,024,025,027 \\
028,029,030,031,034 \\
035,072,073+\sim 0-4\end{array}$ & $\begin{array}{l}\text { Confirmed kill of } \\
\text { unidentified } \\
\text { marine mammal }\end{array}$ & $\begin{array}{l}\text { After kill, milling, } \\
\text { surface-active, } \\
\text { slow travel, travel }\end{array}$ & $\begin{array}{l}\text { Pulsed calls (NASh01, NASh02, } \\
\text { NASh03i, NASh03ii, NASh04i, } \\
\text { NASh04ii, NASh05, NASh06, } \\
\text { variable), echolocation, whistles }\end{array}$ \\
\hline 29 Jun 09 & $15: 08$ & $\begin{array}{l}044,050,104,105,106 \\
107,108,109,110,111 \\
112,113,114,115,116 \\
117,118,119,120,121 \\
140,141,142,143+\sim 5-30\end{array}$ & $\begin{array}{l}\text { Confirmed feeding } \\
\text { on Atlantic herring }\end{array}$ & Slow travel & Whistles \\
\hline $01 \mathrm{Jul} 09$ & $14: 24$ & $\begin{array}{l}122,123,124,125,126 \\
127,128,129,131,132, \\
133,134,138,139,145 \\
146,148,149,150 \\
151+\sim 0-2\end{array}$ & $\begin{array}{l}\text { Confirmed feeding } \\
\text { on Atlantic herring }\end{array}$ & $\begin{array}{l}\text { Milling, slow travel, } \\
\text { travel }\end{array}$ & $\begin{array}{l}\text { Pulsed calls (NASh07, NASh08, } \\
\text { NASh09, NASh10, NASh11, } \\
\text { NASh12, variable), echoloca- } \\
\text { tion, whistles, underwater tail } \\
\text { slaps }\end{array}$ \\
\hline
\end{tabular}

We conducted 10 focal follows (8 with seal-hunting groups and 2 with fish-eating groups), which lasted between 29 min and $2 \mathrm{~h} 36 \mathrm{~min}$ with an average of $1 \mathrm{~h}$ $37 \mathrm{~min}$ and we spent between $10 \mathrm{~min}$ and $1 \mathrm{~h} 40 \mathrm{~min}$ (average: $45 \mathrm{~min}$ ) recording sounds within $500 \mathrm{~m}$ of the animals. Group composition as well as feeding and acoustic behaviour recorded during focal follows, are given in Table 1. The 2 focal follows of fish-eating groups involved different individuals (although both encounters contained unidentified individuals), and we found no photographic matches with seal-hunting groups. Focal follows of seal-hunting groups involved 18 individuals (likely a significant proportion of the seal-hunting assemblage seen around Shetland), although the majority of follows were of the same group of 5 individuals. Fish-eating killer whales were largely silent during one encounter (29 June 2009), but frequently produced pulsed calls, click trains, whistles and underwater tail slaps during the other (1 July 2009). Vocal rates (vocalisations ind. ${ }^{-1} \mathrm{~min}^{-1}$ given as median and quartile range) were $0.48(0.24-0.74)$ for pulsed calls, $0.13(0.07-0.20)$ for click trains and 0.04 (0.02-0.05) for whistles (Fig. 1). Seal-hunting groups showed lower vocal rates for all vocalisation types: 0.01 (0.00-0.14) for pulsed calls, $0.02(0.00-0.06)$ for click trains and $0.00(0.00-0.01)$ for whistles (Fig. 1). Seal- 


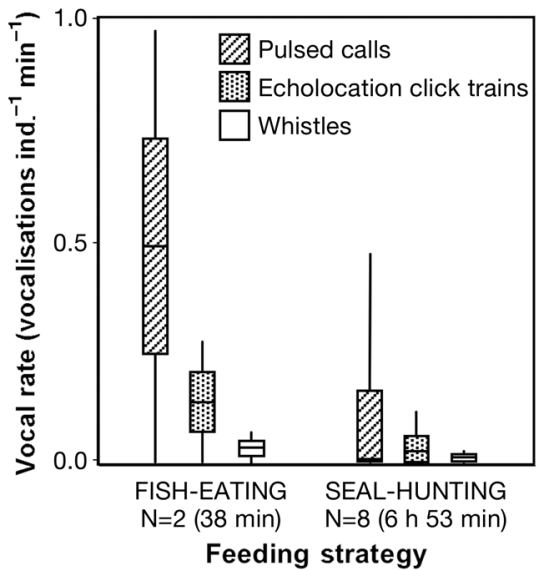

Fig. 1. Orcinus orca. Rates of vocal behaviour (vocalisations ind. ${ }^{-1} \mathrm{~min}^{-1}$ ) for fish-eating and seal-hunting groups of killer whales around Shetland, UK. Rates of pulsed calls, echolocation click trains and whistles are plotted separately. Boxes indicate median and quartile ranges; whiskers delineate full ranges. $\mathrm{N}$ gives the number of encounters with each type of group and the total recording time analysed in parentheses

hunting groups primarily vocalised when milling after a kill or engaged in surface-active behaviour. During behavioural states typically associated with active hunting in other populations (travel, slow-travel or milling; Deecke et al. 2005), the animals were largely silent (Fig. 2).

In total, 469 pulsed calls were recorded from sealhunting groups around Shetland (421 on 28 June 2009), and of these, 85 (83 from 28 June 2009 and 2 from 4 July 2008) were of sufficient quality to extract frequency contours for categorisation. We recorded 656 pulsed calls from herring-eating groups (all on 1 July 2009), of which 35 were good enough to be included in the analysis. The relatively small number of high quality calls for the herring-eating groups is due to frequent overlapping calls and almost constant echolocation and suggests that we have probably only identified a small portion of the total group repertoire of call types. The ARTwarp categorisation algorithm grouped the pulsed calls of seal-hunting groups into 8 categories. Two pairs were subsequently lumped into subtypes of a common call type (NASh03i and ii, and NASh04i and ii) as they differed only in certain parts of the calls (Fig. 3). Pulsed calls of herring-eating groups were divided into 7 categories without obvious subdivision into subtypes. Two additional categories contained only a single example and were thus eliminated from the categorisation. We did not find any call types shared by seal-hunting and herring-eating groups.

\section{DISCUSSION}

Although killer whales regularly use the waters surrounding Shetland, the complex geography of the islands and often challenging weather conditions limited the number of encounters and the time we could spend with the animals. In spite of these limitations, the data presented here provide valuable information about the vocal behaviour and dietary specialisation of killer whales in Shetland waters.

The vocal behaviour of seal-hunting killer whales around Shetland differs markedly from killer whale populations known to specialise on fish, but shows parallels to that of other populations known to specialise on hunting marine mammals. Fish-eating killer whales in the northeastern Pacific are known to feed predominantly on salmon Oncorhynchus spp. (Ford et al. 1998), a prey with insensitive hearing in the frequency bands used by killer whales (Hawkins \& Johnstone 1978), and frequently emit pulsed calls and echolocation clicks in all behavioural states (Ford 1989, BarrettLennard et al. 1996). Only during resting behaviour are rates of these vocalisations somewhat reduced. Whistles in these animals are known to occur in all contexts but increase significantly (to values around 1 whistle ind. ${ }^{-1} \mathrm{~min}^{-1}$ ) during socialising (Ford 1989, Thomsen et al. 2002). Similar patterns have been doc-
Fig. 2. Orcinus orca. Rates of vocal behaviour (vocalisations ind. ${ }^{-1} \mathrm{~min}^{-1}$ ) for seal-hunting groups of killer whales around Shetland, UK, during different behavioural states from 8 focal follows. Rates of pulsed calls, echolocation click trains and whistles are plotted separately. Boxes indicate median and quartile ranges; whiskers delineate full ranges. The number of encounters and total recording time analysed are given for each behavioural state

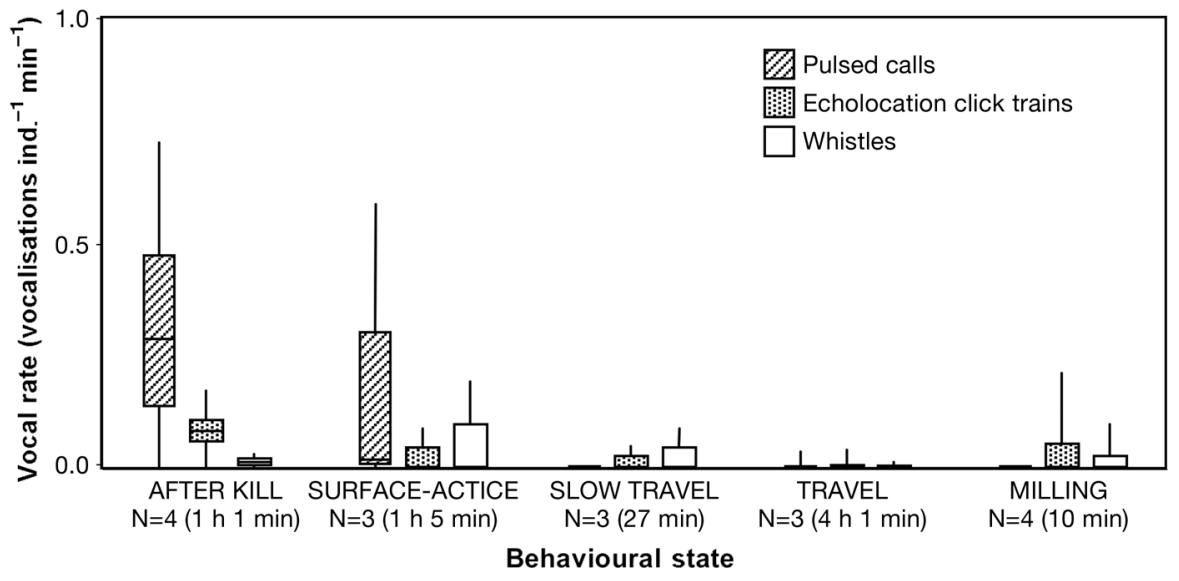


a Seal-eating killer whales
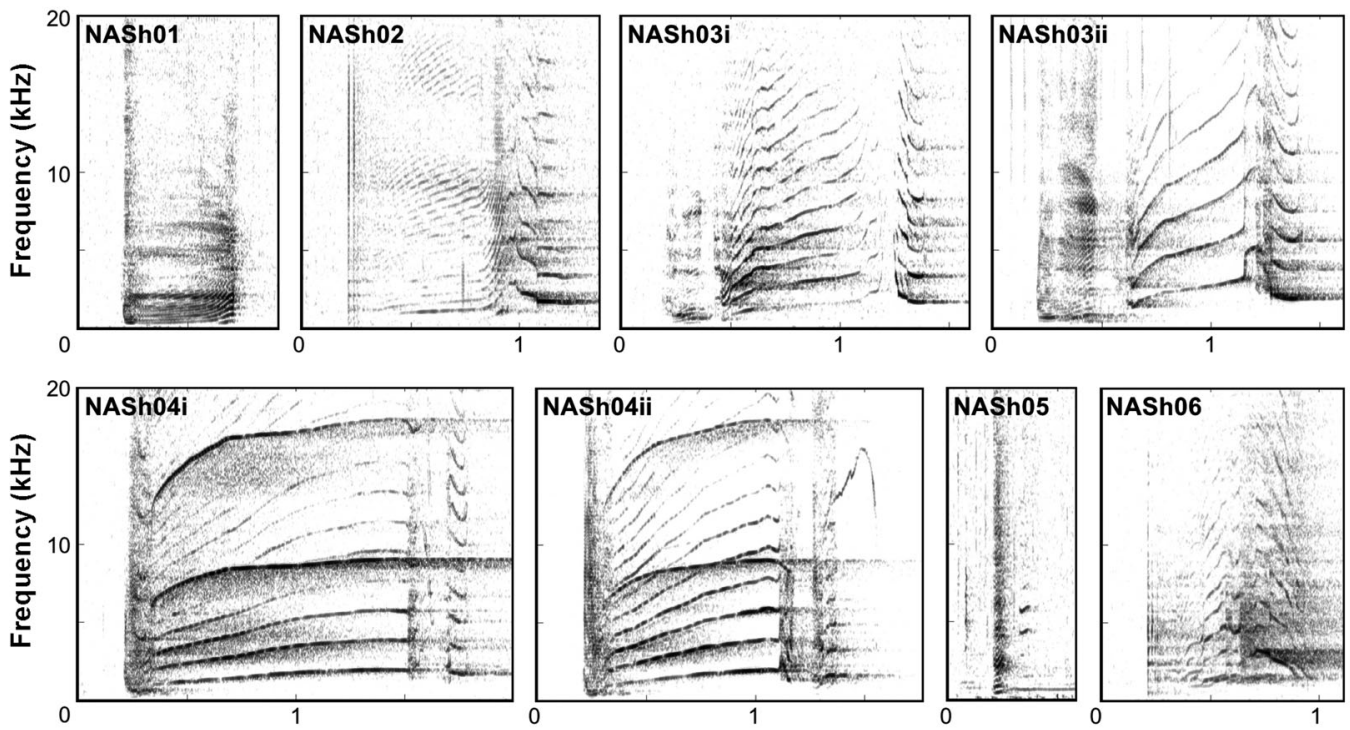

\section{b Herring-eating killer whales}
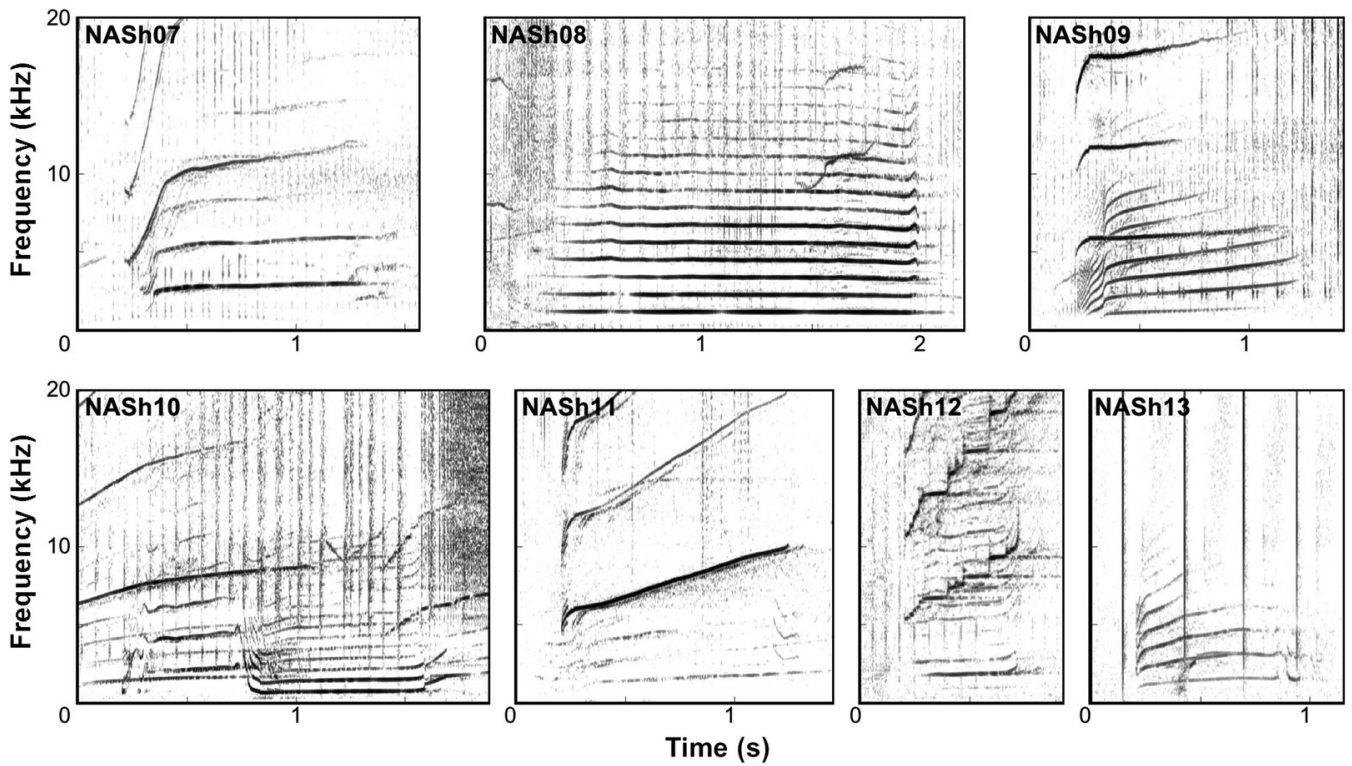

Fig. 3. Orcinus orca. Representative spectrograms of different call types produced by (a) seal-hunting and (b) herring-eating killer whales around Shetland, UK. Recordings were made with a sampling rate of $96 \mathrm{kHz}$. Spectrograms were generated using a Fast Fourier Transform size of 4096 samples, frame length of 1024 samples and $87.5 \%$ overlap between frames resulting in a frequency resolution of $23.4 \mathrm{~Hz}$ and time resolution of $1.3 \mathrm{~ms}$. A Hann window was used for normalisation

umented for fish-eating killer whales in the northwestern Pacific (Tarasyan et al. 2005).

By contrast, mammal-eating killer whales typically restrict all forms of vocal behaviour to a few, narrowly defined contexts. In the southern Indian Ocean, killer whales tend to be silent when hunting southern elephant seals Mirounga leonina around the Crozet Islands, but produce pulsed calls after a successful attack (Guinet 1992). In the northeastern Pacific, tran- sient killer whales are known to feed almost exclusively on marine mammals (Ford et al. 1998). Compared to sympatric fish-eating populations, these animals restrict the use of echolocation (Barrett-Lennard et al. 1996), whistles (Riesch \& Deecke 2011) and pulsed calls (Deecke et al. 2005). Pacific transients produce communicative vocalisations (whistles and pulsed calls) almost exclusively after a successful attack or when engaged in surface-active behaviour 
(Deecke et al. 2005, Riesch \& Deecke 2011). During behaviours associated with active search for prey, these animals are typically silent. Harbour seals and presumably other marine mammals respond very strongly to pulsed calls of mammal-eating killer whales (Deecke et al. 2002), and mammal-eating killer whales appear to restrict vocal behaviour to avoid alerting their acoustically sensitive prey (Barrett-Lennard et al. 1996, Deecke et al. 2002, 2005).

When compared to killer whales that specialise on marine mammal prey elsewhere, groups hunting seals around Shetland show strikingly similar patterns of vocal behaviour (Fig. 2). The animals often travel in silence for hours and only show significant amounts of vocal behaviour after prey capture or during bouts of surface-active behaviour. The silent hunting strategy suggests that these killer whales actively search for marine mammal prey and do not simply capture marine mammals opportunistically when they come across them. All North Atlantic killer whales examined so far are phylogenetically much closer to fish-eating resident populations in the North Pacific than they are to transients (Morin et al. 2010, Foote et al. 2011), which suggests parallel evolution of a silent hunting strategy in the North Pacific and North Atlantic.

The context of vocal behaviour of herring-eating groups around Shetland is less clear-during one encounter dominated by active feeding, the animals frequently produced echolocation clicks, whistles and pulsed calls. During the other encounter, the animals were primarily travelling (a brief bout of foraging was documented prior to the onset of acoustic monitoring) and emitted only 2 whistles in almost $2 \mathrm{~h}$. Herring hear well in the lower part of the frequency band used by killer whales (Enger 1967) and respond to killer whale vocalisations (Wilson \& Dill 2002, Doksæeter et al. 2009), although their anti-predator strategies to avoid killer whale predation may not be as effective as those of marine mammals (Domenici 2001). Whereas silent travel is rare in killer whales specialising on salmonids (Ford 1989), Icelandic and Norwegian herring-eating killer whales often remain silent when travelling, and this reduction of vocal behaviour may be a result of the better hearing of their targeted prey (Simon et al. 2007). A similar reduction in vocalisations can be found in bottlenose dolphins when searching for prey (Jones \& Sayigh 2002, Quick \& Janik 2008).

The 1 July 2009 recording shows that the herringeating killer whales off Shetland performed underwater tail slaps when feeding (Table 1). Tail slaps have been reported from Norwegian and Icelandic killer whales when feeding on herring and generate a characteristic loud percussive noise as one animal strikes a fish school with the tail flukes (Domenici et al. 2000, Simon et al. 2005, van Opzeeland et al. 2005). Ultra- sonic whistles are another indication that herringeating killer whales off Shetland have close affinity with other North Atlantic herring-eating populations. Samarra et al. (2010) reported such whistles with fundamental frequencies exceeding $17 \mathrm{kHz}$ from herringeating killer whales off Norway, Iceland, as well as the animals recorded on 1 July 2009 off Shetland, but not from mammal-eating or fish-eating populations in the North Pacific. In addition, the Shetland animals produced 5 renditions of call type NASh08, whose structure matches call type I36 of Simon et al. (2006) described from herring-eating killer whales off Iceland but not so far from Norway. In both Shetland and Iceland, this call type is typically followed by a tail slap (Fig. 4) and is hypothesised to elicit tighter schooling in the fish and thus increase the number of fish killed or stunned by the strike (Simon et al. 2006). A comparison of the Shetland call repertoires with published spectrograms from North Atlantic killer whales suggests a possible additional match between Shetland herringeaters and killer whales from eastern Iceland (call type NASh10 and call type I5 of Moore et al. 1988), although the quality of the published spectrograms is too poor to establish this unequivocally. These findings suggest that the herring-eating killer whales we recorded off Shetland are either part of, or recently diverged from, the Icelandic herring-eating sub-population and may also visit Icelandic waters on occasion. We did not find any obvious matches between call types of any Shetland groups recorded and published call types from Norway (Moore et al. 1988, van Parijs et al. 2004). Systematic comparisons of our call types and identification photographs with catalogues from other North Atlantic populations will be valuable to further delineate the range of Shetland killer whales.

Photo-identification studies of killer whales from wintering and spawning grounds of the Icelandic summer-spawning and Norwegian spring-spawning stocks of Atlantic herring have documented the same individuals in wintering and spawning grounds of each herring stock, but no movement between stocks (Sigurjónsson et al. 1988, Similä et al. 1996, Simon et al. 2007). Results of genetic analyses were also consistent with maternal lineages following each herring stock and little movement between stocks, but herringeating individuals from Norway, Iceland and Shetland were identified as a single population due to malemediated gene flow (Foote et al. 2011). Our findings may suggest a recent and rare shift from the Icelandic summer-spawning stock to the North Sea stock of Atlantic herring. The fact that ultrasonic whistles are produced by herring-eating killer whales from Iceland, Norway and the herring-eating group off Shetland, but that sharing of stereotyped pulsed calls has so far only been found between Shetland and Iceland, could sug- 


\section{a Shetland}

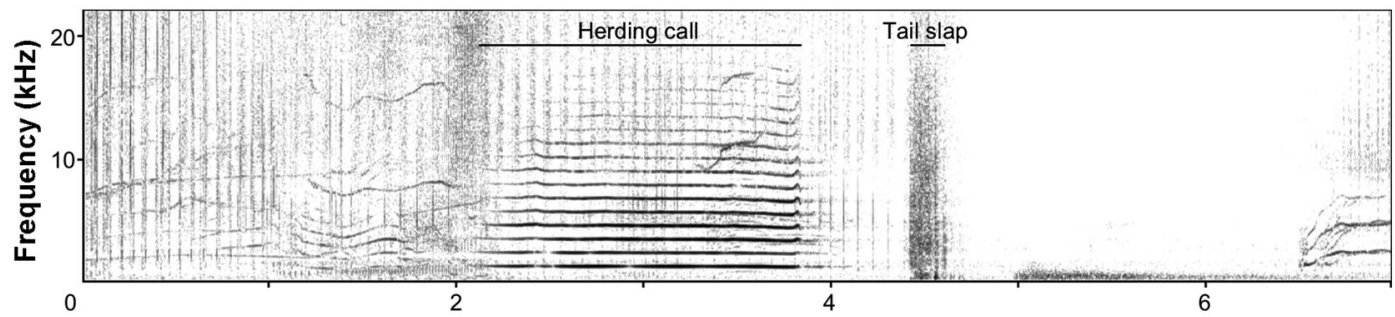

b Iceland

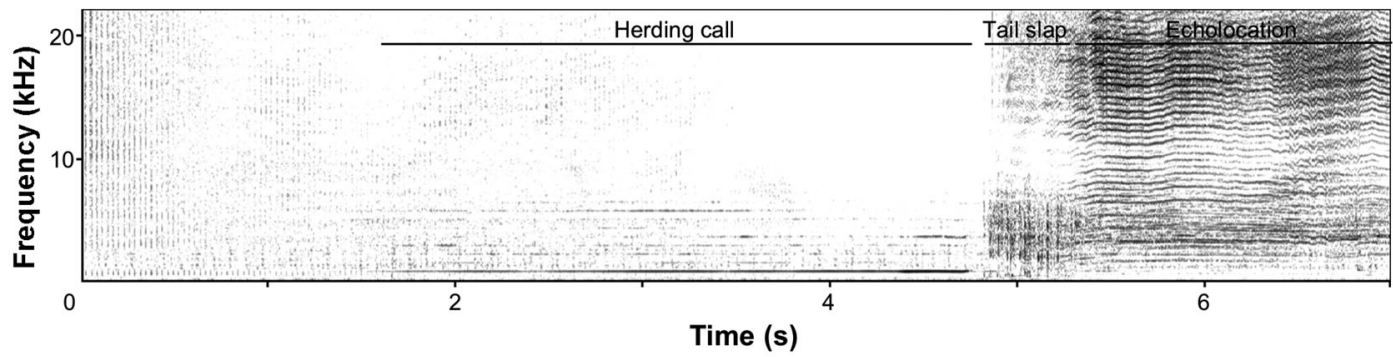

Fig. 4. Orcinus orca. Spectrogram of (a) a herding call (NASh08) followed by a tail slap recorded off Unst, Shetland, UK, and (b) a herding call (call type I36 of Simon et al. 2006) followed by a tail slap and a rapid echolocation click train recorded in the Vestmannaeyjar archipelago off Iceland (courtesy of F. Samarra). Spectrograms were generated using a Fast Fourier Transform size of 4096 samples, frame length of 1024 samples and $75 \%$ overlap between frames resulting in a frequency resolution of $23.4 \mathrm{~Hz}$ and time resolution of $2.6 \mathrm{~ms}$. A Hann window was used for normalisation

gest that whistles and pulsed calls follow different patterns of transmission (as has been described for fisheating North Pacific killer whales; Riesch et al. 2006). A systematic comparison of call and whistle repertoires of North Atlantic killer whales seems called for to address this question.

We did not record ultrasonic whistles from groups observed hunting seals in nearshore waters around Shetland or find any obvious matches between their call types and published vocal repertoires of other North Atlantic killer whales (Moore et al. 1988, van Parijs et al. 2004). Most of the pulsed calls recorded from Shetland seal hunters came from a single recording session. However, one call type (NASh05) was also recorded on a separate occasion (4 July 2008) from a different set of individuals, which suggests that the seal-hunting individuals listed in Table 1 may form part of the same vocal tradition. The fact that we did not find any call types shared between killer whales observed hunting seals and those foraging on herring around Shetland could suggest that they are not close social affiliates. However, the data come from a limited number of encounters, and in some killer whale populations, groups with entirely different repertoires are known to associate frequently and interbreed (Ford 1991, Barrett-Lennard 2000). Further genetic studies are ultimately required to determine the amount of gene flow between seal-hunting and herring-eating groups off Shetland. Whistles may provide better evi- dence for social segregation among Shetland killer whales. In situations where discrete repertoires of pulsed calls occur within the same population, stereotyped whistles can be shared across dialect boundaries determined by pulsed call repertoires (Riesch et al. 2006). However, our preliminary data suggest that the usage of whistles differs substantially among Shetland killer whale groups, as ultrasonic whistles produced by herring-eating groups have so far not been recorded from seal-hunting groups. The difference in usage of high-frequency whistles could represent context-specific variation if these signals are part of a herringfeeding strategy, or could constitute a group-specific variation between herring-eating and seal-hunting groups.

In summary, the vocal behaviour of Shetland killer whales suggests a certain degree of specialisation, either within the same population, or in the form of 2 reproductively isolated populations. Based on high variation of stable isotope values within the maternal lineage associated with each of the Norwegian and Icelandic herring stocks, Foote et al. (2009) suggested that there are differences in the proportion of different components of the diet consumed, while presence of tooth wear in all individuals within these lineages suggests that there is a shared dietary component. We have documented effective acoustic strategies in killer whales around Shetland used to exploit different prey types: silent hunting for sea mammals in seal-hunting 
groups and herding calls thought to concentrate herring in fish-eating groups. The degree of behavioural flexibility of individual animals, and whether the individuals recorded here switch between both types of strategies, remains to be shown. However, the fact that killer whales around Shetland appear to differ in their dietary preferences must be taken into account when estimating the impact of killer whale predation on pinnipeds and when making management decisions affecting killer whales and their prey around the Northern Isles.

Acknowledgements. We thank T. Barton, H. Bolt, E. Doolittle, M. Eggleston, V. Islas, K. MacIver, S. Moss, S. Neves, S. Abel Nielsen, N. Rehn, A. Rocco, A. Shapiro, J. Vilstrup, H. Wood and A. U for providing essential help in the field and S. Kuningas for analysing the identification photographs. Special thanks go to the communities of Shetland and the following organisations for sighting information and logistic support: Scottish Natural Heritage, the Shetland Biological Records Centre, RSPB Shetland, SIC Ferries, Shetland Nature Tours and the Shetland Fishermen's Association. In particular we thank H. Black, J. Brown, R. Fray, K. Hall, P. Harvey, C. Leaky, H. Moncrieff, I. Nicholson, M. Smith, R. Tallack, B. Thomason, G. Tyler and D. Woodford for their contributions. We are indebted to P. Thompson for help in designing the project, help in raising the funds and for providing the research vessel. We thank the Shetland Amenity Trust, the crew of the MFV 'Honestas', and J. Wilson for providing accommodation and additional vessel support. F. Samarra and M. Simon kindly supplied Icelandic killer whale calls for comparison. J. Ford, R. William and 2 anonymous reviewers provided valuable comments on earlier drafts and we thank S. Mariani for helpful discussions on herring mtDNA. Funding for this study was provided by the Carnegie Trust for the Universities of Scotland, the Marine Directorate of the Scottish Government, and Scottish Natural Heritage. V.B.D. was supported by a Marie-Curie Intra-European Fellowship, A.D.F. by a University of Aberdeen 6th Century Scholarship and a Marie Curie Actions 'GENETIME' grant and V.M.J. by a Royal Society University Research Fellowship and a Fellowship at the Centre for Advanced Studies in Berlin. All field research was conducted under licence number 8949 from Scottish Natural Heritage.

\section{LITERATURE CITED}

Altmann J (1974) Observational studies of behavior: sampling methods. Behaviour 49:227-267

> Altschul SF, Gish W, Miller W, Myers EW, Lipman DJ (1990) Basic local alignment search tool. J Mol Biol 215:403-410

Barrett-Lennard LG (2000) Population structure and mating patterns of killer whale populations in the northeastern Pacific, as revealed by DNA analysis. PhD thesis, University of British Columbia, Vancouver

Barrett-Lennard LG, Ford JKB, Heise KA (1996) The mixed blessing of echolocation: differences in sonar use by fisheating and mammal-eating killer whales. Anim Behav 51:553-565

Bolt HE, Harvey PV, Mandleberg L, Foote AD (2009) Occurrence of killer whales in Scottish inshore waters: temporal and spatial patterns relative to the distribution of declining harbour seal populations. Aquat Conserv 19:671-675
Buck JR, Tyack PL (1993) A quantitative measure of similarity for Tursiops truncatus signature whistles. J Acoust Soc Am 94:2497-2506

Couperus AS (1994) Killer whales (Orcinus orca) scavenging on discards of freezer trawlers northeast of the Shetland Islands. Aquat Mamm 20:47-51

Dahlheim ME, White PA (2010) Ecological aspects of transient killer whales (Orcinus orca) as predators in southeastern Alaska. Wildl Biol 6:308-322

Deecke VB, Janik VM (2006) Automated categorization of bioacoustic signals: avoiding perceptual pitfalls. J Acoust Soc Am 119:645-653

$>$ Deecke VB, Ford JKB, Spong P (1999) Quantifying complex patterns of bioacoustic variation: use of a neural network to compare killer whale (Orcinus orca) dialects. J Acoust Soc Am 105:2499-2507

Deecke VB, Slater PJB, Ford JKB (2002) Selective habituation shapes acoustic predator recognition in harbour seals. Nature 420:171-173

> Deecke VB, Ford JKB, Slater PJB (2005) The vocal behaviour of mammal-eating killer whales (Orcinus orca): communicating with costly calls. Anim Behav 69:395-405

$>$ Doksæeter L, Godø OR, Handegard NO, Kvadsheim PH, Lam FPA, Donovan C, Miller PJO (2009) Behavioral responses of herring (Clupea harengus) to 1-2 and 6-7 kHz sonar signals and killer whale feeding sounds. J Acoust Soc Am 125:554-564

> Domenici P (2001) The scaling of locomotor performance in predator-prey encounters: from fish to killer whales. Comp Biochem Physiol A 131:169-182

> Domenici P, Batty RS, Similä T, Ogam E (2000) Killer whales (Orcinus orca) feeding on schooling herring (Clupea harengus) using underwater tail-slaps: kinematic analyses of field observations. J Exp Biol 203:283-294

Enger PS (1967) Hearing in herring. Comp Biochem Physiol 22:527-538

Estes JA, Tinker MT, Williams TM, Doak DF (1998) Killer whale predation on sea otters: linking oceanic and nearshore ecosystems. Science 282:473-476

Evans PGH (1988) Killer whales (Orcinus orca) in British and Irish waters. Rit Fiskid 11:42-54

Foote AD, Newton J, Piertney SB, Willerslev E, Gilbert MTP (2009) Ecological, morphological and genetic divergence of sympatric North Atlantic killer whale populations. Mol Ecol 18:5207-5217

Foote AD, Similä T, Víkingsson GA, Stevick PT (2010) Movement, site fidelity and connectivity in a top marine predator, the killer whale. Evol Ecol 24:803-814

Foote AD, Vilstrup JT, De Stephanis R, Verborgh P and others (2011) Genetic differentiation among North Atlantic killer whale populations. Mol Ecol 20:629-641

Ford JKB (1989) Acoustic behaviour of resident killer whales (Orcinus orca) off Vancouver Island, British Columbia. Can J Zool 67:727-745

> Ford JKB (1991) Vocal traditions among resident killer whales (Orcinus orca) in coastal waters of British Columbia, Canada. Can J Zool 69:1454-1483

Ford JKB, Fisher HD (1982) Killer whale (Orcinus orca) dialects as an indicator of stocks in British Columbia. Rep Int Whaling Comm 32:671-679

Ford JKB, Ellis GM, Barrett-Lennard LG, Morton AB, Palm R, Balcomb KC (1998) Dietary specialization in two sympatric populations of killer whales (Orcinus orca) in coastal British Columbia and adjacent waters. Can J Zool 76:1456-1471

$>$ Ford JKB, Ellis GM, Matkin CO, Wetklo MH, Barrett-Lennard LG, Withler RE (2011) Shark predation and tooth wear in a 
population of northeastern Pacific killer whales. Aquat Biol 11:213-224

Guinet C (1992) Comportement de chasse des orques (Orcinus orca) autour des îles Crozet. Can J Zool 70:1656-1667

> Hawkins AD, Johnstone ADF (1978) The hearing of the Atlantic salmon, Salmo salar. J Fish Biol 13:655-674

> Hoelzel AR, Dahlheim M, Stern SJ (1998) Low genetic variation among killer whales (Orcinus orca) in the Eastern North Pacific and genetic differentiation between foraging specialists. J Hered 89:121-128

Janik VM (2009) Acoustic communication in delphinids. Adv Stud Behav 40:123-157

> Jefferson TA, Stacey PJ, Baird RW (1991) A review of killer whale interactions with other marine mammals: predation to co-existence. Mammal Rev 21:151-180

$>$ Jones GJ, Sayigh LS (2002) Geographic variation in rates of vocal production of free-ranging bottlenose dolphins. Mar Mamm Sci 18:374-393

- Lamont MM, Vida JT, Harvey JT, Jeffries S and others (1996) Genetic substructure of the Pacific harbor seal (Phoca vitulina richardsi) off Washington, Oregon, and California. Mar Mamm Sci 12:402-413

> Lee WJ, Conroy J, Howell WH, Kocher T (1995) Structure and evolution of teleost mitochondrial control regions. J Mol Evol 41:54-66

Lonergan M, Duck CD, Thompson D, Mackey BL, Cunningham L, Boyd IL (2007) Using sparse survey data to investigate the declining abundance of British harbour seals. J Zool (Lond) 271:261-269

> Luque PL, Davis CG, Reid DG, Wang JJ, Pierce GJ (2006) Opportunistic sightings of killer whales from Scottish pelagic trawlers fishing for mackerel and herring off North Scotland (UK) between 2000 and 2006. Aquat Living Resour 19:403-410

Mariani S, Hutchinson WF, Hatfield EMC, Ruzzante DE and others (2005) North Sea herring population structure revealed by microsatellite analysis. Mar Ecol Prog Ser 303: 245-257

Moore SE, Francine JK, Bowles AE, Ford JKB (1988) Analysis of calls of killer whales Orcinus orca from Iceland and Norway. Rit Fiskid 11:225-250

Morin PA, Archer FI, Foote AD, Vilstrup J and others (2010) Complete mitochondrial genome phylogeographic analysis of killer whales (Orcinus orca) indicates multiple species. Genome Res 20:908-916

Pitman RL, Dutton PH (2004) Killer whale predation on a leatherback turtle in the Northeast Pacific. Pac Sci 58: 497-498

Pitman RL, Ensor P (2003) Three forms of killer whales (Orcinus orca) in Antarctic waters. J Cetacean Res Manag 5:131-139

Quick NJ, Janik VM (2008) Whistle rates of wild bottlenose dolphins: influences of group size and behavior. J Comp Psychol 122:305-311

Rice DW (1968) Stomach content and feeding behavior of killer whales in the eastern North Pacific. Norsk Hvalfangst-Tidende 57:36-38

Riesch R, Deecke VB (2011) Whistle communication in mammal-eating killer whales (Orcinus orca): further evidence for acoustic divergence between ecotypes. Behav Ecol Sociobiol 65:1377-1387

Riesch R, Ford JKB, Thomsen F (2006) Stability and group specificity of stereotyped whistles in resident killer whales,

Editorial responsibility: Peter Corkeron,

Ithaca, New York, USA
Orcinus orca, off British Columbia. Anim Behav 71:79-91 Ruzzante DE, Mariani S, Bekkevold D, André C and others (2006) Biocomplexity in a highly migratory pelagic marine fish, Atlantic herring. Proc R Soc Lond B Biol Sci 273: 1459-1464

> Samarra FIP, Deecke VB, Vinding K, Rasmussen MH, Swift RJ, Miller PJO (2010) Killer whales (Orcinus orca) produce ultrasonic whistles. J Acoust Soc Am 128:EL205-EL210

Saulitis EL, Matkin CO, Barrett-Lennard LG, Heise KA, Ellis GM (2000) Foraging strategies of sympatric killer whale (Orcinus orca) populations in Prince William sound. Mar Mamm Sci 16:94-109

Sigurjónsson J, Lyrholm T, Leatherwood S, Jónsson E, Víkingssson GA (1988) Photoidentification of killer whales Orcinus orca off Iceland 1981 through 1986. Rit Fiskid 11: 99-114

Similä T, Holst JC, Christensen I (1996) Occurrence and diet of killer whales in northern Norway: seasonal patterns relative to the distribution and abundance of Norwegian spring-spawning herring. Can J Fish Aquat Sci 53: 769-779

> Simon M, Wahlberg M, Ugarte F, Miller LA (2005) Acoustic characteristics of underwater tail slaps used by Norwegian and Icelandic killer whales (Orcinus orca) to debilitate herring (Clupea harengus). J Exp Biol 208:2459-2466

Simon M, Ugarte F, Wahlberg M, Miller LA (2006) Icelandic killer whale Orcinus orca use a pulsed call suitable for manipulating the schooling behaviour of herring Clupea harengus. Bioacoustics 26:57-74

Simon M, McGregor PK, Ugarte F (2007) The relationship between the acoustic behaviour and surface activity of killer whales (Orcinus orca) that feed on herring (Clupea harengus). Acta Ethol 10:47-53

Springer AM, Estes JA, van Vliet GB, Williams TM and others (2003) Sequential megafaunal collapse in the North Pacific Ocean: an ongoing legacy of industrial whaling? Proc Natl Acad Sci USA 100:12223-12228

Tarasyan KK, Filatova OA, Burdin AM, Hoyt E, Sato H (2005) Keys for the status of killer whales in eastern Kamchatka, Russia: foraging ecology and acoustic behavior. Biosphere Conserv 6:73-83

Thomsen F, Franck D, Ford JKB (2002) On the communicative significance of whistles in wild killer whales (Orcinus orca). Naturwissenschaften 89:404-407

van Opzeeland IC, Corkeron PJ, Leyssen T, Similä T, van Parijs SM (2005) Acoustic behaviour of Norwegian killer whales, Orcinus orca, during carousel and seiner foraging on spring-spawning herring. Aquat Mamm 31:110-119

van Parijs SM, Leyssen T, Similä T (2004) Sounds produced by Norwegian killer whales, Orcinus orca, during capture. J Acoust Soc Am 116:557-560

Weir CR (2002) Killer whales in British waters. Br Wildl 14:106-108

> Williams TM, Estes JA, Doak DF, Springer AM (2004) Killer appetites: assessing the role of predators in ecological communities. Ecology 85:3373-3384

- Wilson B, Dill LM (2002) Pacific herring respond to simulated odontocete echolocation sounds. Can J Fish Aquat Sci 59: 542-553

Yurk H, Barrett-Lennard LG, Ford JKB, Matkin CO (2002) Cultural transmission within maternal lineages: vocal clans in resident killer whales in southern Alaska. Anim Behav 63:1103-1119

Submitted: December 27, 2010; Accepted: May 6, 2011

Proofs received from author(s): June 29, 2011 